\title{
Analysis of passive-sampler monitored atmospheric ammonia at 74 sites across southern Ontario, Canada
}

\author{
X. H. Yao ${ }^{1}$ and L. Zhang $^{2}$ \\ ${ }^{1}$ Key Lab of Marine Environmental Science and Ecology, Ministry of Education, Ocean University of China, Qingdao, China \\ ${ }^{2}$ Air Quality Research Division, Science and Technology Branch, Environment Canada, Toronto, Canada
}

Correspondence to: L. Zhang (leiming.zhang@ec.gc.ca)

Received: 11 July 2013 - Published in Biogeosciences Discuss.: 5 August 2013

Revised: 27 October 2013 - Accepted: 6 November 2013 - Published: 4 December 2013

\begin{abstract}
Weekly/biweekly concentrations of atmospheric $\mathrm{NH}_{3}$ were collected using passive samplers at 74 sites across southern Ontario, Canada, during the period from June 2006 to March 2007 with eighteen sites running as early as March 2006. The annual average of $\mathrm{NH}_{3}$ (AAN) at all the sites across southwestern Ontario was over $1 \mu \mathrm{g} \mathrm{m}^{-3}$, a value that was recently proposed as the new critical level for protecting vegetation. High AAN values $\left(3.6-6.1 \mu \mathrm{g} \mathrm{m}^{-3}\right)$ were observed at eight sites located inside the intensive livestock production zones. AAN values at the sites across southeastern Ontario were generally lower than $1 \mu \mathrm{g} \mathrm{m}^{-3}$ and the values were less than $0.4 \mu \mathrm{g} \mathrm{m}^{-3}$ at non-agricultural sites. Agricultural sites generally showed the highest concentrations in spring to summer and the lowest in winter, but the occurrence time of the peak concentration varied among the sites, which could be due to their different land use and thus different fertilizer application intensities or periods. Seasonal trends of $\mathrm{NH}_{3}$ concentration at some non-agricultural sites were somewhat similar to those at the agricultural sites, but the peak concentration appeared a few weeks later than at the agricultural sites. Surprisingly, at several remote non-agricultural sites, $\mathrm{NH}_{3}$ concentrations were not decreasing in winter and were sometimes increasing to a level higher than those in summer, which could be caused by different transport mechanisms in different seasons. A sharp increase in $\mathrm{NH}_{3}$ concentration was also surprisingly observed at 20 out of the 74 sites during the coldest two weeks when ambient temperature was lower than $-7^{\circ} \mathrm{C}$, and cannot be explained by known sources or with existing knowledge. The $\mathrm{NH}_{3}$ emission inventory for the region of southern Ontario was evaluated using the measurement data and emissions within two small zones in this region were identified to be potentially underestimated.
\end{abstract}

\section{Introduction}

Atmospheric ammonia $\left(\mathrm{NH}_{3}\right)$ is an important reactive nitrogen compound in the geosphere and biosphere of the earth. $\mathrm{NH}_{3}$ gas has been found to cause direct adverse effects on plant community composition even at low concentration levels and the value of $1 \mu \mathrm{g} \mathrm{m}^{-3}$ has been proposed as a new critical level for protecting vegetation (Cape et al., 2009). $\mathrm{NH}_{3}$ gas can react with acidic gases to form ammonium salts and increase concentration of fine particles in the atmosphere (Chan and Yao, 2008; Yao and Zhang, 2012; Zhang et al., 2007, 2012). In the past several decades the decrease of ammonia emission is slower than that of acidifying sulfur and nitrogen species in many countries. Thus, the impact of ammonia on ecosystems attracts more attention (Galloway et al., 2008; Herridge et al., 2008; Sutton et al., 2009).

The origins of $\mathrm{NH}_{3}$ vary, depending on land use. For example, in intensive agricultural zones, agricultural activities such as livestock farming and $\mathrm{N}$ fertilizer application are generally recognized as the major contributors to $\mathrm{NH}_{3}$ (Beusen et al., 2008; Salazar et al., 2012; Sheppard et al., 2010; Sutton et al., 1998; Zbieranowski and Aherne, 2012, 2013). In remote areas, $\mathrm{NH}_{3}$ can originate from natural emissions associated with microbial activity or atmospheric transport (Sutton et al., 2009). Because $\mathrm{NH}_{3}$ is very reactive and is also removed fast through dry and wet deposition, its concentration decreases rapidly with distance from the sources (Theobald et al., 2012). However, particulate ammonium formed from $\mathrm{NH}_{3}$ can be transported far away from sources (Asman et al., 1998; Wen et al., 2013) and semi-volatile ammonium salts can be transformed back to $\mathrm{NH}_{3}$ under certain meteorological and chemical conditions (Seinfeld and Pandis, 2006; Yao et al., 2011; Zhang et al., 2008). 
Assessing the impact of $\mathrm{NH}_{3}$ on ecosystem health, air quality and climate requires accurate prediction of ammonia and ammonium distributions at local and regional scales. $\mathrm{NH}_{3}$ emission inventories are thus needed as input for chemical transport modes. To improve the outdated $\mathrm{NH}_{3}$ emission inventory in southern Ontario, Environment Canada established a high spatial-resolution monitoring network comprising 74 sites and measured weekly/biweekly $\mathrm{NH}_{3}$ concentrations during the period from June 2006 to March 2007 (Lillyman et al., 2009). The measurements of $\mathrm{NH}_{3}$ at eighteen of these sites were made as early as March 2006. The data set not only allows an evaluation and improvement of the Canadian $\mathrm{NH}_{3}$ emission inventory for the region of southern Ontario, but also allows a better understanding $\mathrm{NH}_{3}$-related sciences through in-depth data analysis and data-model comparison (e.g., Wen et al., 2013).

The purpose of the present study is to understand the geographical and seasonal patterns of $\mathrm{NH}_{3}$ in southern Ontario and to identify factors controlling these patterns through comprehensive data analysis. In the following sections, the geographical distributions of $\mathrm{NH}_{3}$ are first presented so the major sources of $\mathrm{NH}_{3}$ can be revealed (Sect. 3.1). The study region is then split into different concentration zones and the seasonal variations of $\mathrm{NH}_{3}$ in the different zones are studied in details (Sects. 3.2-3.4). To understand the phenomena identified in Sect. 3, various explanations were explored (Sect. 4). Finally, a brief evaluation of Environment Canada's most recent $\mathrm{NH}_{3}$ emission inventory was conducted (Sect. 5) using knowledge obtained in Sects. 3 and 4.

\section{Experimental}

Funded by the National Agri-Environmental Standards Initiative (NAESI), a project known as the Southern Ontario Ammonia Passive Sampler Survey (SOAPSS) was launched in March 2006 to monitor atmospheric $\mathrm{NH}_{3}$ in southern Ontario, Canada (Lillyman et al., 2009). A total of 74 sites were selected and evenly distributed at agriculture zones and remote non-agriculture zones across southern Ontario with distances between the sites of approximately $20 \mathrm{~km}$ (Fig. 1a). Commercially available Ogawa passive samplers were used to monitor $\mathrm{NH}_{3}$ in the high concentration areas of the network during the warm months; slightly larger customdesigned passive samplers were used to monitor $\mathrm{NH}_{3}$ in the low concentration areas and throughout the winter period. The description of the Ogawa sampler and sampling methodology is documented in Roadman et al. (2003). For quality control purposes, the two types of passive samplers were compared against the $\mathrm{NH}_{3}$ gas analyzer and denuder at one selected site (Egbert) for one year period before the campaign started. As shown in Fig. S1, the concentrations of $\mathrm{NH}_{3}$ measured by Ogawa passive samplers and custom-designed passive samplers were both comparable to those collected by the other instruments. No systematic differences were found between the two types of passive samples used in the present study. Besides, the differences between the passive samples and the active samples were generally less than $20 \%$, which is within the proposed limit for passive samplers for $\mathrm{NH}_{3}$ (Sutton et al., 2001). Comparability of passive samplers to complex methods has also been well established in literature (Cape et al., 2004; Puchalski et al., 2011; Sutton et al., 2001).

From March to May 2006, only eighteen sites started running for consistency check and sampler evaluation. All the 74 sites measured ambient concentration of $\mathrm{NH}_{3}$ starting June 2006. Thus, only approximately $20 \%$ of sites had the $\mathrm{NH}_{3}$ data between March and May 2006 despite the fact that the strongest $\mathrm{NH}_{3}$ emissions occur in this region in the month of May (Lillyman et al., 2009). Note that weekly samples were collected before 5 December 2006 while biweekly samples were collected after this date in expectation of low concentration of $\mathrm{NH}_{3}$ in the cold seasons. The project provided highly spatial-resolved atmospheric $\mathrm{NH}_{3}$ concentration data although with relatively low temporal resolution.

\section{Results}

\subsection{Geographical distribution of $\mathrm{NH}_{3}$ concentration}

According to recent publications, more than $80 \%$ of $\mathrm{NH}_{3}$ emissions in southern Ontario are from agricultural activity while non-agricultural sources (e.g., industrial sources, vehicle emissions, open sources (except animals), non-industrial fuel combustion, miscellaneous and incineration) contribute to the remaining < $20 \%$ (Lillyman et al., 2009; Environment Canada, 2013). For the agricultural generated emissions, livestock production accounts for approximately $80 \%$, with the remaining $20 \%$ being mainly associated with fertilizer application. However, two potential sources are not included in the emission inventory of $\mathrm{NH}_{3}$ in Canada (Lillyman et al., 2009). One is biogenic $\mathrm{N}$ fixation in soil followed by soil $\mathrm{N}$ cycling processes that release $\mathrm{NH}_{3}$ from soil and/or via plants to the atmosphere (Dabney and Bouldin, 1990). The other is atmospheric deposition of $\mathrm{NO}_{\mathrm{y}}$ to soil followed by soil $\mathrm{N}$ cycling processes that release $\mathrm{NH}_{3}$ to the atmosphere. These emissions can be considered as natural emission or re-emission of predeposited $\mathrm{N}$ that is converted to $\mathrm{NH}_{3}$.

Annual average $\mathrm{NH}_{3}$ concentration (AAN - calculated using nine to 12 month data depending on data availability for individual sites) was first compared with the latest emission inventory for a consistency check, and was then analyzed for geographical distributions. The geographical distribution of AAN (Fig. 1b) was generally consistent with that of $\mathrm{NH}_{3}$ emissions across southern Ontario (Fig. S2), as can be seen from their similar geographical patterns. Hot spots in both concentration and emission were centered in the agricultural zones (Figs. S2 and S3). A correlation analysis between AAN and the gridded emission extracted from the 

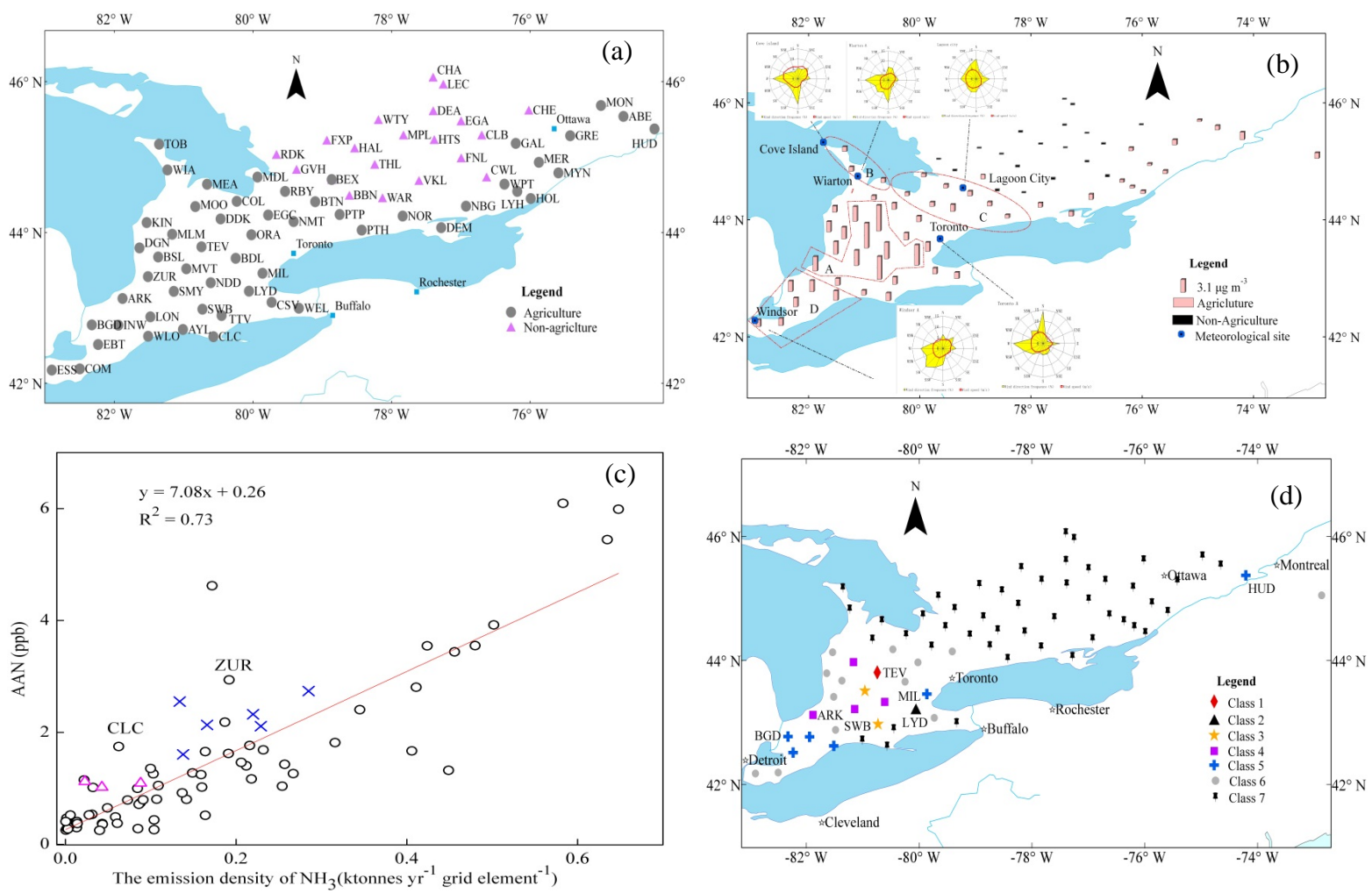

Fig. 1. (a) location and symbol of the 74 sampling sites across southern Ontario; (b) geographical distributions of annual average $\mathrm{NH}_{3}$ (AAN) with superimposed wind rose at five meteorological stations; (c) correlation between AAN and gridded emission. Pink triangle and blue cross are Zones B and D sites, respectively, shown in Fig. 1b; and (d) classification of the 74 sites.

grids containing the sites shows a high correlation with the square of correlation coefficient value of 0.73 (Fig. 1c).

The highest AAN was observed at eight sites (Arkona (ARK), Lynden (LYD), Mildmay (MLM), Milverton (MVT), New Dundee (NDD), St. Marys (SMY), Sweaburg (SWB) and Teviotdale (TEV)) and ranged from 3.6 to $6.1 \mu \mathrm{g} \mathrm{m}{ }^{-3}$ (Fig. 1b). These sites were in a region of active livestock production (Fig. S3, Zbieranowski and Aherne, 2012, 2013). AAN in agricultural zones was generally larger than $1 \mu \mathrm{g} \mathrm{m}{ }^{-3}$, except at seven sites (Galbraith (GAL), Holland (HOL), Lyndhurst (LYH), Merrickville (MER), Montebello (MON), Maynard (MYN) and Westport CAPMON (WPT)) where an AAN in the range of $0.4-0.7 \mu \mathrm{g} \mathrm{m}^{-3}$ was observed. The low AAN values were likely associated with low intensity of agricultural activity. AAN lower than $1 \mu \mathrm{g} \mathrm{m}^{-3}$ was observed at rural and remote non-agricultural-zone sites (highlighted in black in Fig. 1b).

Based on the proposed critical level of $1 \mu \mathrm{g} \mathrm{m}^{-3}$ for protecting vulnerable vegetation such as lichens and mosses and critical level of $3 \mu \mathrm{g} \mathrm{m}^{-3}$ for other vegetation (Cape et al., 2009), the 74 monitoring sites were classified into three concentration categories for easy interpretation in Sect. 3.23.4 (i.e., high (AAN $>3 \mu \mathrm{g} \mathrm{m}^{-3}$ ), medium $\left(1-3 \mu \mathrm{g} \mathrm{m}^{-3}\right.$ ) and low $\left(<1 \mu \mathrm{g} \mathrm{m}^{-3}\right)$ concentration categories). Category 1
(AAN $>3 \mu \mathrm{g} \mathrm{m}^{-3}$ ) has eight sites as listed above. At seven of the eight sites, weekly/biweekly concentrations higher than $10 \mu \mathrm{g} \mathrm{m}^{-3}$ were observed in a few samples. Category 2 ( 1 to $\left.3 \mu \mathrm{g} \mathrm{m}^{-3}\right)$ has a total of 36 sites and Category $3\left(<1 \mu \mathrm{g} \mathrm{m}^{-3}\right)$ has the remaining 30 sites.

It is noticed that sites belonging to the same concentration category did not necessarily have the same temporal pattern. For example, even the eight sites in Category 1 which are situated close to each other had different temporal patterns. The seasonal patterns in each category are discussed in detail below. Thus, the 74 sites were further split into seven classes using hierarchical cluster analysis so the geographical distribution of sites having similar temporal patterns and concentration ranges can be easily identified (Fig. 1d). The eight sites in Category 1 took the first four classes because of their very high concentrations and different temporal patterns (Zone A in Fig. $1 \mathrm{~b}$ and d). Class 5 consists of six sites (Inwood (INW), Mildmay (MIL), Eberts (EBT), West Lorne (WLO), Hudson (HUD), Brigden (BGD)) and had an AAN ranged from 1.8 to $2.6 \mu \mathrm{g} \mathrm{m}^{-3}$. Four of the six sites in Class 5 (lowerleft corner in Fig. 1d) were located near the strong $\mathrm{NO}_{\mathrm{x}}$ emissions (Fig. S4). $\mathrm{NO}_{2}$ can be oxidized to $\mathrm{HNO}_{3}$ which can then possibly form $\mathrm{NH}_{4} \mathrm{NO}_{3}$ in the atmosphere, thereby leading to depletion of atmospheric $\mathrm{NH}_{3}$. Conversely, higher 

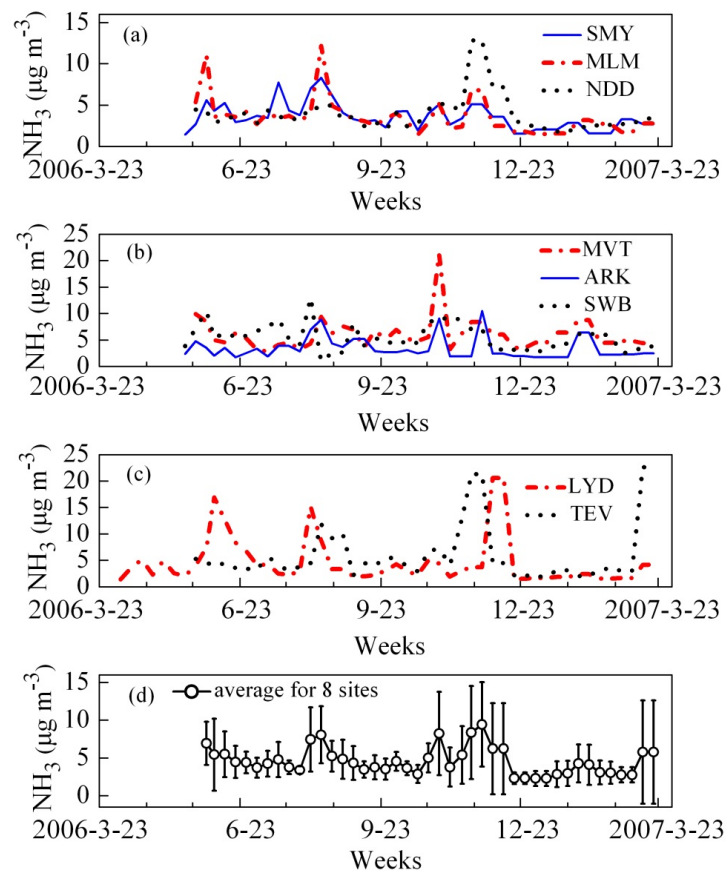

Fig. 2. Temporal variations of $\mathrm{NH}_{3}$ in 2006-2007 at high concentration zone sites: (a) three sites having no spike in winter, (b) three sites having a spike in winter, (c) two sites having data before June, and (d) the spatially averaged value over eight sites.

atmospheric deposition of $\mathrm{NO}_{\mathrm{y}}$ in high $\mathrm{NO}_{\mathrm{x}}$ emission areas can add $\mathrm{N}$ to soils which could be a potential emission source of $\mathrm{NH}_{3}$. In Class 6, 12 sites in southwestern Ontario and one site $\sim 500 \mathrm{~km}$ northeast were grouped together. Their AAN ranged from 1.3 to $2.9 \mu \mathrm{g} \mathrm{m}^{-3}$. Of these, 12 sites were scattered over $\sim 200 \mathrm{~km}$ range and encircling sites in Classes 1 to 5 (Fig. 3b). Similar land use and simultaneous agricultural activity at the 12 sites probably led to their consistent temporal variations of $\mathrm{NH}_{3}$ concentrations, leading to them being grouped together.

The remaining 47 sites were defined as Class 7, of which 43 sites were situated in southeastern Ontario and 4 sites were located near Lake Erie. Their AAN ranged from 0.2 to $1.8 \mu \mathrm{g} \mathrm{m}^{-3}$. The dominant wind direction in southwestern Ontario was from the west and southwest (Fig. 2a and Bein et al., 2008). Under the dominant wind condition, most of the sites in Class 7 are located downwind of those zones with higher concentrations of $\mathrm{NH}_{3}$. Regional transport of semivolatile ammonium salts followed by evaporation or regional transport of $\mathrm{NH}_{3}$ could contribute to the $\mathrm{NH}_{3}$ observed at most of sites in Class 7 as discussed later, leading to temporal variations of ambient $\mathrm{NH}_{3}$ concentration in Class 7 being different from those in Class 6. Note that the 36 sites in Category 2 cover all sites in Classes 5 and 6 and also include 17 out of 47 sites in Class 7, and the 30 sites in Category 3 all belonging to Class 7 .
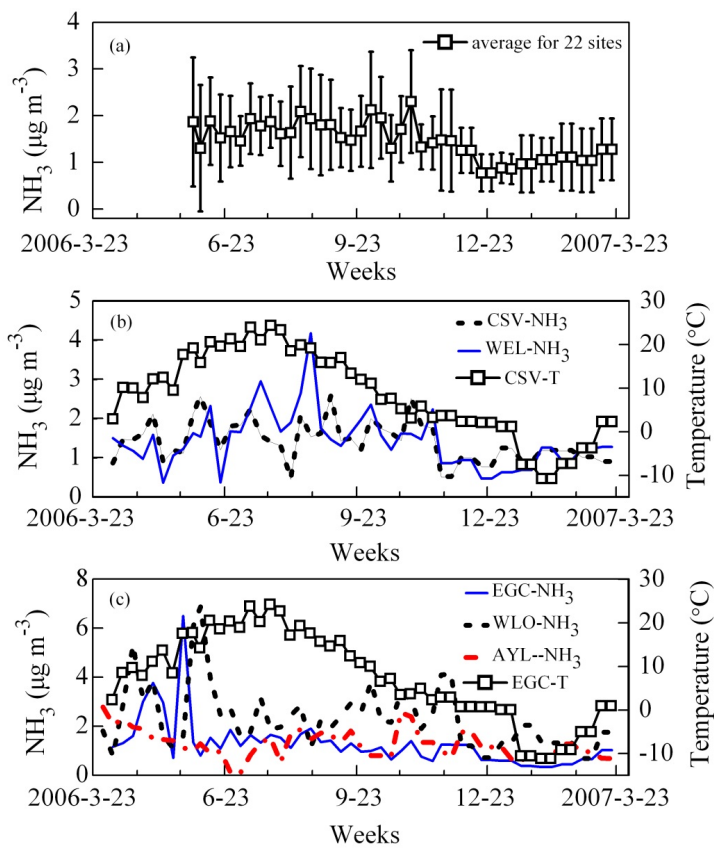

Fig. 3. Temporal variations of $\mathrm{NH}_{3}$ in 2006-2007 at sites located in the medium concentration zones but without spikes during the coldest temperature periods: (a) the spatially averaged value over 22 sites, (b) two sites having no spikes before the early of June, and (c) three sites having spikes before the early of June.

\subsection{Seasonal variations of $\mathrm{NH}_{3}$ in high concentration zones}

Eight sites having an AAN higher than $3 \mu \mathrm{g} \mathrm{m}^{-3}$ were distributed within intensive livestock zones (zone A in Fig. 1b). The time series of weekly/biweekly samples are shown in Fig. 2. A few samples having spikes of $>10 \mu \mathrm{g} \mathrm{m}^{-3}$ were observed at seven of the eight sites and two spikes of 7.7$8.3 \mu \mathrm{g} \mathrm{m}^{-3}$ were observed at the remaining site of SMY. Based on the on-site record, approximately $50 \%$ of these spikes $\left(>10 \mu \mathrm{g} \mathrm{m}^{-3}\right)$ can be explained by manure application. Manure application on soil was previously reported to rapidly release $\mathrm{NH}_{3}$ to the atmosphere in a few days, leading to a significant $\mathrm{N}$ loss (Sommer and Hutchings, 2001; Misselbrook et al., 2005). During the sampling periods of another $10 \%$ of these peaks $>10 \mu \mathrm{g} \mathrm{m}^{-3}$, either smoke or grass cutting was recorded, but no manure application was recorded. For the remaining $40 \%$ of the spikes, the on-site record showed no manure application, no smoke, and no grass cutting. It is speculated that these unexplained spikes might be due to $\mathrm{N}$ fertilizer application, although the on-site record did not include the term. Like manure application on soil, $\mathrm{N}$ fertilizer application on soil can also cause 10-30\% $\mathrm{N}$ loss by releasing $\mathrm{NH}_{3}$ to ambient air in the initial 3-5 days after the application (Salazar et al., 2012).

When the concentration of $\mathrm{NH}_{3}$ in each sample was averaged over the eight sites, there was a decreasing trend from 
early June to mid-July (Fig. 2d). The decrease was likely a decrease in emissions after early June across southern Ontario (Lillyman et al., 2009). The peaks of $\mathrm{NH}_{3}$ in late July and November were probably due to occasional manure or fertilizer application.

A sharp decrease, e.g., $\sim 50 \%$, in $\mathrm{NH}_{3}$ concentration was observed starting around mid-December. The decrease could be caused by one or more factors as follows. Emissions from livestock production in southern Ontario were estimated to decrease by $\sim 80 \%$ in November and December compared to those in October (Lillyman et al., 2009). This does not necessarily mean that the livestock production was also reduced by $80 \%$. Instead, the reduced emissions were due to a combination of reduced livestock production, different treatment of animal wastes and different environmental conditions. Fertilizer application in December, January and February was also negligible (Lillyman et al., 2009). Besides, the snow season in southern Ontario generally starts in November and the highest snowfall occurs in December, January and February (http://www.wunderground.com/global/ stations/71265.html, Fig. S5). Thick snow cover should reduce soil emissions substantially. Daily average temperature generally decreases to below the freezing mark in December and the surface soil $T$ (in the top 1-2 cm depth) usually has a rapid response to the change of ambient $T$ in a few hours (Marshall and Holmes, 1988). Low soil $T$ lowers microbial activity and thus soil emissions of $\mathrm{NH}_{3}$ (Misselbrook et al., 2001; Sutton et al., 2009). Moreover, the lower ambient $T$ could favor formation of $\mathrm{NH}_{4} \mathrm{NO}_{3}$ in the atmosphere, which has been observed at a few places of southern Ontario (Yao et al., 2011; Zhang et al., 2008), and thus led the depletion of $\mathrm{NH}_{3}$ gas.

However, a biweekly peak of $\mathrm{NH}_{3}$ concentration was observed in the early of February 2007 at MVT (8.8 ppb), ARK (6.4 ppb) and SWB (6.2 ppb) when the lowest ambient $T$ occurred. The peak concentration of $\mathrm{NH}_{3}$ at each site was 12 times higher than the site's average value during the period from December 2006 to March 2007. This phenomenon was not detected at the other five sites. The peaks in the coldest weeks were also observed at some sites belonging to the other two concentration categories and are discussed in detail in Sect. 4.

\subsection{Seasonal variations of $\mathrm{NH}_{3}$ in medium concentration zones}

Thirty-six sites had an AAN in the range of 1 to $3 \mu \mathrm{g} \mathrm{m}{ }^{-3}$ and are further classified into two sub-Categories here, i.e., Category $2 \mathrm{~A}$ for sites having no peaks occurred under the lowest $T\left(<-7^{\circ} \mathrm{C}\right)$ and Category 2B for sites having peaks under the lowest $T$. In the cold seasons, weather conditions in the southern Ontario were generally controlled by synoptic system (Bein et al., 2008). Thus, temporal tends of ambient temperature were all similar at the 74 sites (Figs. 2-4).
Apparently, ambient weather conditions alone cannot explain the difference between Categories 2A and 2B.

Category $2 \mathrm{~A}$ includes 22 sites. The concentration of $\mathrm{NH}_{3}$ in each weekly/biweekly sample was averaged over 22 sites and the time series of the spatially averaged value was obtained for analysis. The simple approach can make the common trends among sites more obvious. The disadvantage of this approach is that it smoothes the distinctive trends associated with specific sites. The spatially averaged value of $\mathrm{NH}_{3}$ over the 22 sites in each weekly/biweekly sample fluctuated at $1.8 \pm 0.9 \mu \mathrm{g} \mathrm{m}^{-3}$ (mean \pm standard deviation, Fig. 3a) during the period from 1 June to 7 November 2006 The spatially averaged value decreased by approximately $20 \%$ and fluctuated at $1.4 \pm 0.7 \mu \mathrm{g} \mathrm{m}^{-3}$ during the period from 7 November to 19 December 2006. The spatially averaged value sharply decreased down to $0.8 \pm 0.4 \mu \mathrm{g} \mathrm{m}^{-3}$ in mid-December 2006 and then slowly increased and reached $1.3 \pm 0.7 \mu \mathrm{g} \mathrm{m}^{-3}$ at the end of March 2007. Similar to those in the high concentration zones, the elevated concentrations before or during early June were only observed at some agricultural-zone sites, such as at West Lorne (WLO) and Egbert (EGC), and were absent at other agricultural-zone sites, such as Caistorville (CSV), Welland (WEL) and Aylmer (AYL) (Fig. 3b, c). This indicated that not all agriculturalzone sites had enhanced emissions of $\mathrm{NH}_{3}$ before or during early June, although the period was the traditional manure and fertilizer application season. This is likely due to the different land use since different crops require different fertilization periods (Fig. S3).

Category 2B includes 14 sites (13 sites in Fig. 4a and one site in Fig. S6). The spatially averaged value of $\mathrm{NH}_{3}$ over 13 sites in each weekly/biweekly sample of Category 2B was approximately $10 \%$ higher than that in Category $2 \mathrm{~A}$. The seasonal trend of the spatially averaged value in Category $2 \mathrm{~B}$ was generally similar to that in Category $2 \mathrm{~A}$, except that there was a peak of $\mathrm{NH}_{3}$ concentration at low ambient $T\left(<-7^{\circ} \mathrm{C}\right)$ in Category 2B. Again, an increase of $\mathrm{NH}_{3}$ concentration was observed before or during early June at several agricultural-zone sites, such as Inwood (INW), Comber (COM) and Brigden (BGD) (Fig. 4b), but was absent at other sites, such as Essex (ESS), Teeterville (TTV) and Longwoods (LON). Moreover, one agriculture-zone site (Clear Creek, CLC) had much high concentrations of $\mathrm{NH}_{3}$ in the weekly samples collected between 13-20 June $\left(19.3 \mu \mathrm{g} \mathrm{m}^{-3}\right)$ and 20-27 June $\left(13.0 \mu \mathrm{g} \mathrm{m}^{-3}\right) 2006$ (Fig. S6). The peak concentrations were 7-10 times higher than the AAN of $1.7 \mu \mathrm{g} \mathrm{m}^{-3}$ and were probably due to $\mathrm{N}$ fertilizer application (no manure application was recorded during these two weeks).

\subsection{Seasonal variations of $\mathrm{NH}_{3}$ in low concentration zones}

Thirty sites had an AAN $<1 \mu \mathrm{g} \mathrm{m}^{-3}$. The spatially averaged value of $\mathrm{NH}_{3}$ over the 30 sites in each weekly/biweekly 

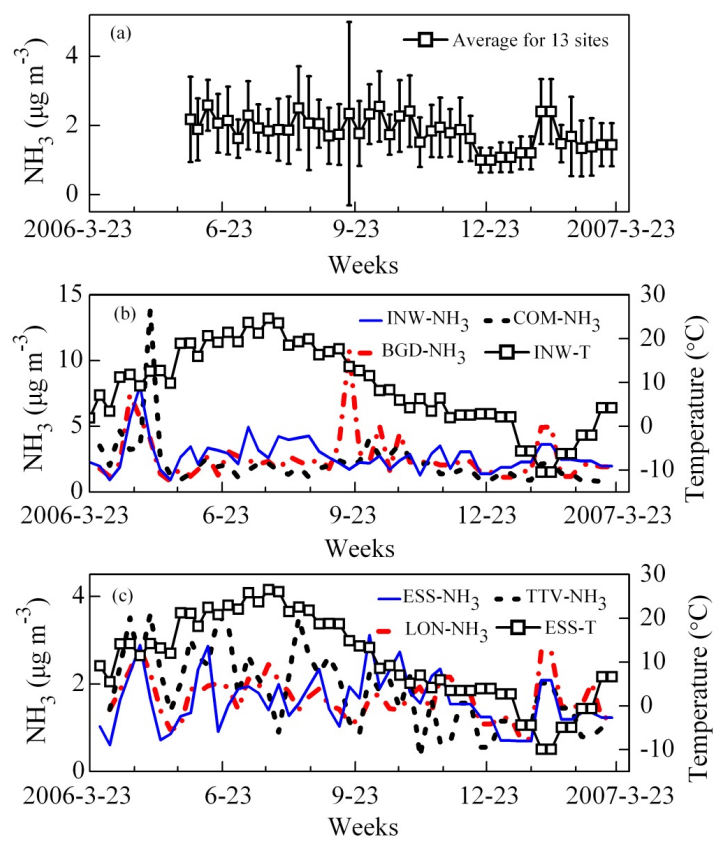

Fig. 4. Temporal variations of $\mathrm{NH}_{3}$ in 2006-2007at sites located in the medium concentration zones sites but with spikes during the coldest temperature periods: (a) the spatially averaged value over 13 sites, (b) three sites having spikes before the early of June, and (c) three sites having no spikes before the early of June.

sample fluctuated around $0.4 \pm 0.3 \mu \mathrm{g} \mathrm{m}^{-3}$ during the period from August 2006 to March 2007, except during the period from 13 June to 1 August 2006 (Fig. 5a) when the spatially averaged value increased by $50-100 \%$ and reached a maximum of $0.8 \mu \mathrm{g} \mathrm{m}^{-3}$ during mid-July 2006. Twenty out of the 30 sites were situated at the remote non-agriculture zone where no manure and fertilizer application occurred. The temperature effect cannot explain the high concentration levels during the six-week period because the highest ambient temperature occurred in the early of August (Fig. 5a, b). Regional transport of $\mathrm{NH}_{3}$ from the high concentration zones may have led to the higher concentration of $\mathrm{NH}_{3}$ in the low concentration zones. However, the broad peak of $\mathrm{NH}_{3}$ in the Category 3 had a few weeks delay when compared to the peaks observed at the sites in high concentration zones in southwestern Ontario (Figs. 2-4), the latter cases being consistent with seasonal variations of $\mathrm{NH}_{3}$ emissions associated with agricultural activities. For example, as reported by Lillyman et al. (2009), the agricultural emissions of $\mathrm{NH}_{3}$ in June or in July across southern Ontario were only approximately one third of those in May. Zbieranowski and Aherne (2012, 2013) also pointed out that the highest concentration of $\mathrm{NH}_{3}$ across agricultural zones of southern Ontario occurred in May. As presented above, a few peaks of $\mathrm{NH}_{3}$ in the high concentration zones indeed occurred before or during early June 2006.


Fig. 5. Temporal variations of $\mathrm{NH}_{3}$ in 2006-2007 at sites located in the low concentration zones: (a) the spatially averaged value over 30 sites, (b) three sites having data before June, and (c) three sites having no data before June.

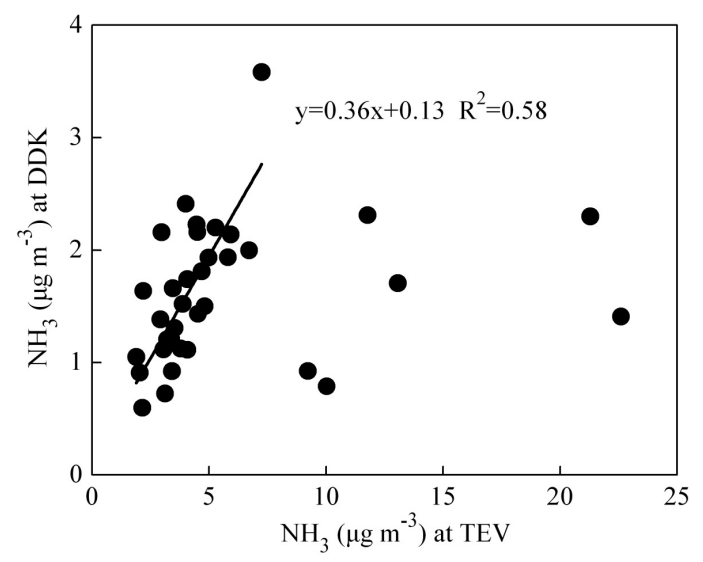

Fig. 6. Correlation of $\mathrm{NH}_{3}$ between sites TEV and DDK.

However, the enhanced emissions of $\mathrm{NH}_{3}$ from agricultural and non-agricultural activity before or during early June cannot explain the broad peak during the period from 13 June to 1 August 2006 in Category 3 (Fig. 5a). The lifetime of atmospheric ammonia is relatively short (e.g., a few days, Wen et al., 2013). It was unlikely to take such a long time (e.g., more than a week) to transport $\mathrm{NH}_{3}$ from higher concentration zones to these low concentration sites with known wind conditions, especially considering that dominant wind was from the west and the southwest (Fig. 1b). As discussed later, negative correlations were obtained for $\mathrm{NH}_{3}$ concentration measured at tens of sites between southeastern Ontario 
and southwestern Ontario. Various possible transport mechanisms are discussed in Sect. 4.

Again, at three sites (RBY, Vansickle (VAL) and GAL), a peak of $\mathrm{NH}_{3}$ was observed in January-February 2007 when $T$ was as low as $-10^{\circ} \mathrm{C}$ (Fig. 7c). The peak concentration of $\mathrm{NH}_{3}$ observed at each site was 2-3 times higher than the site's average value during the period from December 2006 to March 2007.

\section{Discussion}

\subsection{Outstanding issues and proposed explanations}

The geographical and seasonal patterns of $\mathrm{NH}_{3}$ concentrations presented above can largely be explained by known emission sources and meteorological factors. There are, however, some phenomena that need more explanations. These include (1) peak concentrations at remote non-agricultural sites appeared a few weeks later than at the majority of agricultural sites; (2) $\mathrm{NH}_{3}$ concentrations were higher in winter than in summer at some remote non-agricultural sites; and (3) the sharp increase in $\mathrm{NH}_{3}$ concentration at 20 out of the 74 sites during the coldest two weeks when ambient temperature was lower than $-7^{\circ} \mathrm{C}$.

Differences in local meteorology, for example, the frequency of stable atmospheric condition which typically causes concentration accumulation, might play a small role, however, not enough to explain the phenomena (1) and (2) listed above. Local emissions, which were assumed to be the highest in summer, cannot explain the even higher observed $\mathrm{NH}_{3}$ concentrations in winter at remote sites. Manure dumping in mid-winter by farmers, while forbidden by the law, could be a reason for phenomena (3) listed above. This would explain peaks of $\mathrm{NH}_{3}$ concentrations in the agricultural zones, but cannot explain the peaks in the nonagricultural zones which were several hundred kilometers away from the potential sources.

One possibility causing phenomena (1) and (2) above could be due to the transport mechanisms that are unique for $\mathrm{NH}_{3}$ than for other pollutants. Here we proposed two transport mechanisms based on existing knowledge. The first one is the indirect transport of $\mathrm{NH}_{3}$. Air-soil and air-plant exchanges of $\mathrm{NH}_{3}$ are bi-directional, especially in agricultural areas (Walker et al., 2013). Although $\mathrm{NH}_{3}$ concentration decreased rapidly with distance from sources, the deposited $\mathrm{NH}_{3}$ could be emitted back into the atmosphere and underwent further transportation. Thus, $\mathrm{NH}_{3}$ emitted from intensive agricultural zones travels a short distance every day and takes much longer time to reach remote areas several hundred kilometers away. The second one is the transport of semi-volatile ammonium salts which were formed in $\mathrm{NH}_{3}$ rich area and evaporated in low $\mathrm{NH}_{3}$ area. An earlier study showed that $\mathrm{NH}_{3}$ was enough to neutralize both sulfate and nitrate at agricultural areas, but not enough to neutralize ni- trate at remote areas (Zhang et al., 2008). This provides some evidences of the proposed mechanism. These proposed transport mechanisms can best be examined using high spatial resolution concentration measurements with a reasonable time resolution combined with high-resolution model simulation, which unfortunately cannot be accommodated in the present study. However, we managed to look more closely at our data and found some evidences that seem to agree, if not to verify, the above proposed mechanisms, as discussed below.

\subsection{Regional transport of $\mathrm{NH}_{3}$ to low concentration zones at $\mathrm{T}>\mathrm{0}^{\circ} \mathrm{C}$}

Direct transport of $\mathrm{NH}_{3}$ was likely unimportant from the agricultural areas to the remote areas. To estimate the maximum contributions of direct atmospheric transport between these two regions, we chose two sites that had a good correlation in $\mathrm{NH}_{3}$ concentration, but were much closer with each other than the distance between the two regions. The relationship between the site TEV, which had the highest AAN $\left(6.1 \mu \mathrm{g} \mathrm{m}^{-3}\right)$ among all of the 74 sties, and the site DDK, which was $30 \mathrm{~km}$ downwind of TEV (noting that the dominant wind was from the west and the southwest) and had an AAN of $1.7 \mu \mathrm{g} \mathrm{m}^{-3}$, was investigated as an example. A moderately good correlation, i.e., $\left[\mathrm{NH}_{3}\right]_{\mathrm{DDK}}=0.36 *\left[\mathrm{NH}_{3}\right]_{\mathrm{TEV}}+$ 0.13 with $R^{2}=0.58(P<0.01)$, was obtained for $\mathrm{NH}_{3}$ concentration between the two sites when six $\mathrm{NH}_{3}$ spikes $>9 \mu \mathrm{m}^{-3}$ at TEV were excluded (Fig. 6). The good correlation was not necessarily a result of direct transport. Similar meteorological conditions coupled with similar land use and soil nitrogen content could also result in a good correlation if local emissions were the main contributor. Theoretical modeling results by Theobald et al. (2012) showed a twoorder of magnitude decrease in $\mathrm{NH}_{3}$ concentration in just $1000 \mathrm{~m}$ distance from agriculture sources. The direct transport to $30 \mathrm{~km}$ downwind could be much smaller. During five of the six spikes at TEV, the weekly concentrations of $\mathrm{NH}_{3}$ at TEV were approximately one order of magnitude higher than those at DDK during the same period. This suggested that at most $10 \%$ of $\mathrm{NH}_{3}$ at TEV can be transported to DDK. Thus, the slope of 0.36 was overwhelmingly caused by similar meteorological conditions. Moreover, as discussed above, the concentrations of $\mathrm{NH}_{3}$ at most of the agriculture sites were higher than $1 \mu \mathrm{g} \mathrm{m}^{-3}$. It is thus reasonable to assume that the local emission of $\mathrm{NH}_{3}$ at DDK contributed $1 \mu \mathrm{g} \mathrm{m}^{-3}$ to the total of $1.7 \mu \mathrm{g} \mathrm{m}^{-3}$ (AAN). This suggests that $\mathrm{NH}_{3}$ from atmospheric transport only contributed $0.7 \mu \mathrm{g} \mathrm{m}^{-3}$ to the AAN at DDK, which was only one tenth of the AAN at TEV.

However, when the concentrations of $\mathrm{NH}_{3}$ in each pair of 74 sites were correlated to each other, a few negative correlations were obtained between southwestern sites and southeastern sites. Table 1 and Fig. S7 showed these pairs in which negative correlations were obtained with $R^{2}>0.4$ and $P<0.01$. 

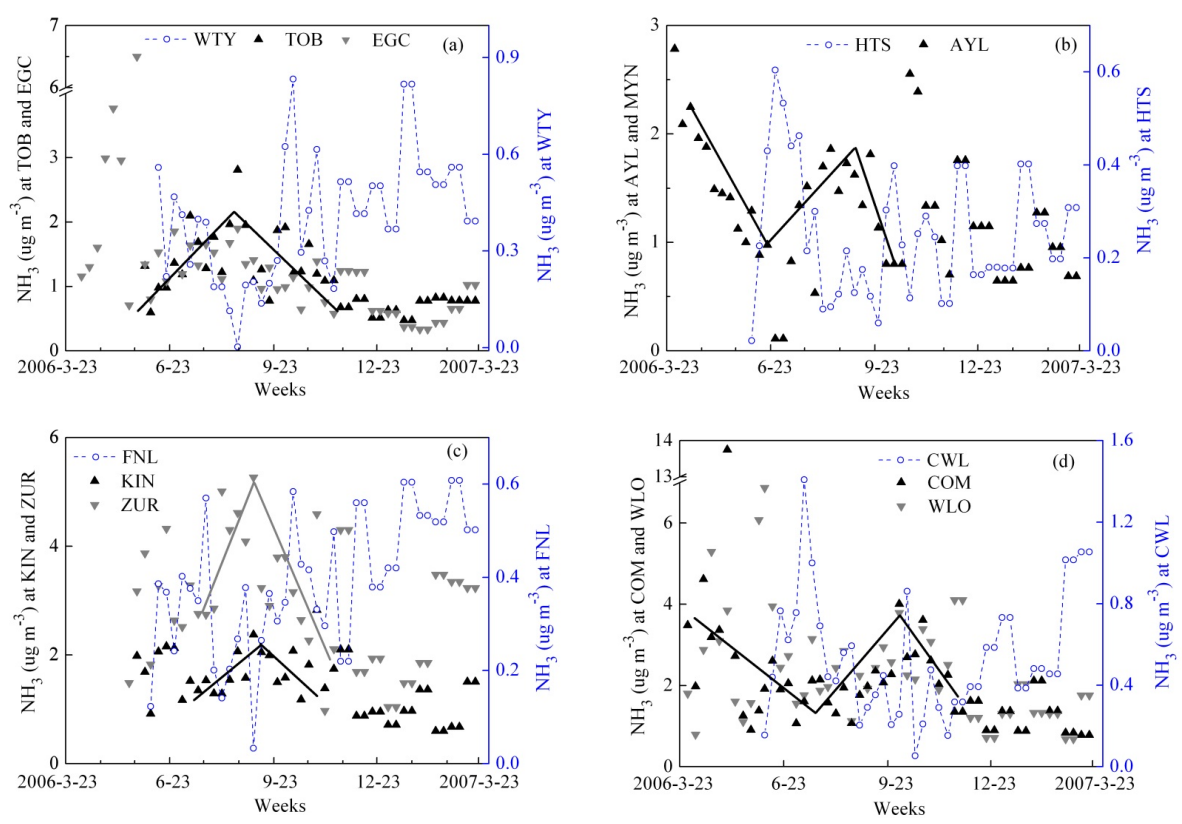

Fig. 7. Comparison of time series of $\mathrm{NH}_{3}$ concentration between southwestern and southeastern sites (the straight lines are trend lines artificially drawn).


Fig. 8. (a) distribution of sites with elevated $\mathrm{NH}_{3}$ in the coldest weeks, and (b) correlations between peak (or net increase) concentrations and annual averages for these sites.

The dominant wind from the west and the southwest likely played an important role on regional transport of $\mathrm{NH}_{3}$ from southwestern Ontario to southeastern Ontario (Wen et al., 2013). In addition, land-lake breeze (land wind is from the south in daytime while lake wind is from the north at night) might have influenced the regional transport of $\mathrm{NH}_{3}$ to the southeastern sites adjacent to Lake Ontario. Regional transport signal of $\mathrm{NH}_{3}$ at the southeastern sites adjacent to Lake Ontario could be different from that at sites dozens or hundreds kilometers north of Lake Ontario. To explore the role of regional transport in the negative correlations of $\mathrm{NH}_{3}$ identified between southwestern and southeastern sites, $\mathrm{NH}_{3}$ concentration at four se- lected sites in southeastern Ontario were analyzed in detail. The four selected sites, Whitney (WTY) $\rightarrow$ Hartsmere $($ HTS $) \rightarrow$ Fernleigh (FNL) $\rightarrow$ Crow Lake (CWL), follow a northwest to southeast transect, and are all located in remote non-agricultural zones. Considering that there was no agricultural activity in the remote non-agricultural zones, ammonia collected there should be from a combination of nature emissions and regional transport. Natural emissions of $\mathrm{NH}_{3}$ were found to increase exponentially with air temperature (Zhang et al., 2010; Flechard et al., 2013). It is thus reasonable to assume that the observed summer $\mathrm{NH}_{3}$ level represents the maximum contributions from natural emissions. 
Table 1. Negative correlation between each pair of the sites.

\begin{tabular}{llr}
\hline Southwestern site & Southeastern site & $R^{2}(P<0.01)$ \\
\hline \multirow{4}{*}{ FNL } & EGC & 0.49 \\
& KIN & 0.47 \\
& MIL & 0.43 \\
& MLM & 0.49 \\
& SMY & 0.43 \\
& WLO & 0.52 \\
& ZUR & 0.47 \\
\hline \multirow{2}{*}{ MON } & MOO & 0.40 \\
& TEV & 0.41 \\
\multirow{2}{*}{ AYL } & ZUR & 0.51 \\
\hline \multirow{2}{*}{ CWL } & HTS & 0.42 \\
& MYN & 0.48 \\
\hline \multirow{2}{*}{ WTY } & COM & 0.42 \\
& WLO & 0.40 \\
\hline \multirow{2}{*}{ GAL } & TOB & 0.54 \\
\hline
\end{tabular}

At WTY (a remote non-agriculture site), $\mathrm{NH}_{3}$ concentrations were negatively correlated to those at Tobermory (TOB) and at EGC (Table 1 and Fig. $7 \mathrm{a}$ ). $\mathrm{NH}_{3}$ at TOB fluctuated and increased during the period from 6 June to $29 \mathrm{Au}$ gust 2006 and then fluctuated and decreased till the end of December 2006. The temporal trend matched that of $T$ well $\left(R^{2}=0.44\right.$ with $\left.P<0.01\right)$. Higher ambient $T$ usually disfavors formation of ammonium nitrate which is the sink of $\mathrm{NH}_{3}$ gas (Seinfeld and Pandis, 2006). In contrast, higher soil $T$ favors decomposition of organics, but inhibits the nitrification process (Grunditz and Dalhammar, 2001; Pagans et al., 2006). Thus, higher soil $T$ usually results in higher emissions of $\mathrm{NH}_{3}$ (Lillyman et al., 2009). The temporal variation of $\mathrm{NH}_{3}$ at EGC was generally similar to that at TOB. However, during the period from 6 June to 29 August 2006, $\mathrm{NH}_{3}$ at WTY fluctuated and decreased and reached a minimum of $0.2 \mu \mathrm{g} \mathrm{m}^{-3}$ in August, which probably represented the maximum contribution from local emissions at this site because $T$ was the highest during this period. Higher concentrations of $\mathrm{NH}_{3}$ at WTY in early June were probably from external transport of $\mathrm{NH}_{3}$ associated with enhanced agricultural emissions in May. With the external transport signal decreasing from June to August, the concentrations of $\mathrm{NH}_{3}$ at WTY decreased accordingly. From the end of September to the end of October, $\mathrm{NH}_{3}$ at WTY fluctuated and increased while $T$ decreased. The increase of $\mathrm{NH}_{3}$ in concentration probably reflected the enhancement of new external transport signal.
At HTS (a remote non-agriculture site), concentrations of $\mathrm{NH}_{3}$ were negatively correlated with that at AYL. The concentration of $\mathrm{NH}_{3}$ at HTS increased from $<0.1 \mu \mathrm{g} \mathrm{m}^{-3}$ in early June to the maximum value of $0.6 \mu \mathrm{g} \mathrm{m}^{-3}$ at the end of June (Fig. 7b). From early July to the end of July, the concentration of $\mathrm{NH}_{3}$ at HTS decreased to $\sim 0.1 \mu \mathrm{g} \mathrm{m}^{-3}$ and remained at $0.1-0.2 \mu \mathrm{g} \mathrm{m}^{-3}$ in August and September. The $0.2 \mu \mathrm{g} \mathrm{m}^{-3}$ should represent the maximum contribution from local emissions at this site because $T$ was the highest in the early of August. The increase of $\mathrm{NH}_{3}$ at HTS in June 2006 was probably due to transport of $\mathrm{NH}_{3}$ from the southwestern agriculture zones with higher emissions of $\mathrm{NH}_{3}$. The maximum value at HTS had more than two weeks delay when compared to the spikes of $\mathrm{NH}_{3}$ observed in the southwestern Ontario (Figs. 2-4). The proposed transport mechanisms might have played a role, and the first mechanism is likely more important than the second one during hot seasons. The decrease of $\mathrm{NH}_{3}$ at HTS from early July 2006 was probably due to a decreased external transport signal. In early October, $\mathrm{NH}_{3}$ rapidly increased and then fluctuated at a higher value, which should attributed to a new external transport signal arriving at HTS.

At FNL (a remote non-agriculture site), $\mathrm{NH}_{3}$ concentrations were negatively correlated with those at Kincardine (KIN) and Zurich (ZUR) (Table 1 and Fig. 7c). A broad peak of $\mathrm{NH}_{3}$ at $\mathrm{FNL}$ occurred during the period from the mid-June to the end of July. $\mathrm{NH}_{3}$ rapidly decreased to $\sim 0.2 \mu \mathrm{g} \mathrm{m}^{-3}$ in early August and stayed low through the rest of August. Similar to discussions for the above two sites, $0.2 \mu \mathrm{g} \mathrm{m}^{-3}$ was proposed to be the maximum contribution from local emissions at FNL. The broad peak between June and July was also likely related to regional transport. The delayed peak at FNL compared to those at KIN and ZUR seems to agree with the first proposed mechanisms above. $\mathrm{NH}_{3}$ gradually increased from early September to mid-October, suggesting a new transport signal appeared. After mid-October, $\mathrm{NH}_{3}$ fluctuated at higher concentration levels. The reverse temporal trend was generally observed at KIN and ZUR, leading to their concentrations of $\mathrm{NH}_{3}$ being negatively correlated to that at FNL.

At CWL (a remote non-agriculture site), $\mathrm{NH}_{3}$ concentrations were negatively correlated with those at $\mathrm{COM}$ and WLO (Fig. 7d). The concentrations of $\mathrm{NH}_{3}$ at CWL increased from $0.2 \mu \mathrm{g} \mathrm{m}^{-3}$ in early June to the maximum concentration of $1.4 \mathrm{\mu g} \mathrm{m}^{-3}$ during 11-18 July and then decreased. The reverse tend was observed at COM and WLO. The concentration peak of $\mathrm{NH}_{3}$ at CWL in mid-July was also likely associated with regional transport of $\mathrm{NH}_{3}$. The delayed peak seems to agree with the first proposed mechanisms above. This is because the peak has over one month delay, compared to high agricultural emissions of $\mathrm{NH}_{3}$ in May and the early of June at sites of southwestern Ontario. The concentrations of $\mathrm{NH}_{3}$ at $\mathrm{CWL}$ reached a lower value $\left(\sim 0.2 \mu \mathrm{g} \mathrm{m}^{-3}\right)$ in September and then fluctuated between September and November. $0.2 \mu \mathrm{g} \mathrm{m}^{-3}$ could also represent 
the maximum contribution from local sources to the observed $\mathrm{NH}_{3}$ concentration. The concentrations of $\mathrm{NH}_{3}$ at CWL gradually increased after the end of November, suggesting the arrival of a new transport signal.

\subsection{Regional transport of $\mathrm{NH}_{3}$ to low concentration zones at $T<0^{\circ} \mathrm{C}$}

As shown in Figs. 5 and 7, no decreases of $\mathrm{NH}_{3}$ concentrations were observed at these low concentration sites during the period from December 2006 through March 2007. At a few sites, the concentrations of $\mathrm{NH}_{3}$ in the winter even increased to some extent and were higher than their respective concentrations in June and July 2006. For example, $\mathrm{NH}_{3}$ at WTY and FNL gradually increased from the lowest concentration at the end of August to a higher value in mid-October and then fluctuated at the higher value through the winter. The average value of $\mathrm{NH}_{3}\left(0.5 \pm 0.2 \mu \mathrm{g} \mathrm{m}^{-3}\right)$ at WTY during the period from the mid-October 2006 through March 2007 was significantly higher than the average $\left(0.4 \pm 0.1 \mu \mathrm{g} \mathrm{m}^{-3}\right)$ during the period from June through July 2006 with $95 \%$ confidence. The same phenomenon was also observed at FNL.

The maximum contribution from local emissions to $\mathrm{NH}_{3}$ measured at WTY and FNL was likely $\leq 0.2 \mu \mathrm{g} \mathrm{m}^{-3}$ as discussed in Sect. 4.2. The proposed transport mechanisms should also apply in cold season, which might have increased $\mathrm{NH}_{3}$ at WTY and FNL. Due to the very low $T$ and thus low natural and re-emissions of $\mathrm{NH}_{3}$ along the transport paths, the first mechanism should play a much smaller role in cold than in hot season. Thus, the second proposed transport mechanism should be more important. In the cold seasons, $\mathrm{NH}_{4} \mathrm{NO}_{3}$ can be formed in the polluted environments of the southern Ontario (Zhang et al., 2008, Yao et al., 2011, Yao and Zhang, 2012). The chemically formed $\mathrm{NH}_{4} \mathrm{NO}_{3}$ in the atmosphere was mainly present in the particles $<2.5 \mu \mathrm{m}$ and can be transported over dozens to hundreds of kilometers, depending on ambient conditions. When the $\mathrm{NH}_{4} \mathrm{NO}_{3}$ arrived at receptor sites with low concentrations of $\mathrm{NH}_{3}$, the product of $\left[\mathrm{HNO}_{3}\right] *\left[\mathrm{NH}_{3}\right]$ was less than the equilibrium constant of $\mathrm{NH}_{4} \mathrm{NO}_{3}$ and resulted in the release of $\mathrm{NH}_{3}$ gas from the particle phase. In the warm seasons from June to August, the chemically formed $\mathrm{NH}_{4} \mathrm{NO}_{3}$ in the atmosphere was often thermodynamically disfavored in southern Ontario (Zhang et al., 2008) and ammonium was mainly associated with sulfate in atmospheric particles.

\subsection{Analysis of elevated $\mathrm{NH}_{3}$ concentration at $T<-7^{\circ} \mathrm{C}$}

As mentioned above, the elevated concentrations were observed at 20 out of the 74 total sites when the biweekly averaged ambient $T$ sharply decreased to below $-7^{\circ} \mathrm{C}$. In southwestern Ontario, these sites were situated either at Algonquin Arch or evenly distributed at the two sides of the
Arch (Fig. 8a). Note that Algonquin Arch was formed in Paleozoic time (Johnson et al., 1992). However, the sites in southeastern Ontario were located on a much narrow line, which almost overlapped the demarcation line between nonagriculture and agriculture zones in this region.

Among these sites, a good correlation existed between the elevated concentration and associated AAN; so was the case between the elevated concentration and the net increase of $\mathrm{NH}_{3}$ (calculated as the difference between the elevated concentration and the minimum concentration in January and February) (Fig. 8b). At the southwestern sites, the good correlation implies that the elevated $\mathrm{NH}_{3}$ concentration were mainly due to local emissions. However, agricultural activity was limited in January and February. Emissions from accident outdoor agricultural activity at the lowest ambient $T$ were unlikely. Indoor agricultural activity should neither be the main cause for the elevated concentration. This is because indoor activity occurred throughout the whole winter and should not cause elevated concentration only in the coldest two weeks and only at specific sites. In southeastern Ontario, the elevated $\mathrm{NH}_{3}$ supposed to be related to regional transport of $\mathrm{NH}_{3}$. However, regional transport should cause an increase of $\mathrm{NH}_{3}$ in a broad band zone downwind of source zones instead of only on a narrow line along $\sim 300 \mathrm{~km}$ length in the middle of agricultural and non-agricultural areas. Recently, Yao et al. (2013) found that traffic emissions of $\mathrm{NH}_{3}$ yielded a negligible contribution to atmospheric ammonia in southern Ontario. Thus, the elevated $\mathrm{NH}_{3}$ under extremely low $T$ at sites in both agricultural and non-agricultural regions cannot be explained by existing knowledge.

Satellite data during that period showed that the percentage of snow-covered soil across the southern Ontario was approximately $100 \%$, except over lakes, rivers and traffic roads, etc. (Fig. S5). The emission of $\mathrm{NH}_{3}$ from snowcovered soil under harsh low-temperature conditions were traditionally considered to be very low (Sommer and Hutchings, 2001; Sutton et al., 2009; Sheppard et al., 2010). However, a few studies had demonstrated that microbial processes continued in snow-covered soils, and a significant portion of decomposition and production of microbially derived trace gases can occur in snow-covered soils (Groffman et al., 2001; Nemergut et al., 2005; Edwards et al., 2006). This is because snow can insulate soil and protect the microbial community from freezing ambient conditions (Nemergut et al., 2005). These previous studies and observations in this study suggested that emissions of $\mathrm{NH}_{3}$ from snow-covered soil need to be re-examined.

\section{Missing emission sources of $\mathrm{NH}_{3}$ in two agricultural zones}

When the geographical distribution of $\mathrm{NH}_{3}$ concentration was compared with that of $\mathrm{NH}_{3}$ emission inventory recently developed by Environment Canada, inconsistence was found 
at two zones (B and D) as outlined in Fig. 1b. Three sites (TOB, WIA and MEA) between Lake Huron and Georgian Bay (circled B zone in Fig. 1b) were approximately 100$150 \mathrm{~km}$ distance from the high $\mathrm{NH}_{3}$ emission zone (circled A zone in Fig. 1b). As shown in Fig. 1c, AAN at the three sites, which was $\sim 1.1 \mu \mathrm{g} \mathrm{m}^{-3}$, was situated above the regression line between AAN vs. the emission density, suggesting the potential underestimation of $\mathrm{NH}_{3}$ emission in B zone. Direct regional transport of $\mathrm{NH}_{3}$ from A zone to $\mathrm{B}$ zone was likely unimportant because of the $100-150 \mathrm{~km}$ distance between the two zones. In fact, AAN at MOO, a site between A zone and $\mathrm{B}$ zone and approximately $30 \mathrm{~km}$ from $\mathrm{A}$ zone, was only $1.0 \mu \mathrm{g} \mathrm{m}^{-3}$. $\mathrm{NH}_{3}$ transported from A zone to B zone should be diluted to a much higher extent than that from $\mathrm{A}$ zone to the site of $\mathrm{MOO}$ due to further distance to $\mathrm{B}$ zone. Thus, $\mathrm{NH}_{3}$ emission from $\mathrm{B}$ zone was thought to be underestimated by a factor of 1 to 3 . Another zone which $\mathrm{NH}_{3}$ emission was also potentially underestimated was D zone. As shown in Fig. 1c, AAN at six sites was also situated above the regression line between AAN vs. the emission density. $\mathrm{NH}_{3}$ emission from D zone seemed to be underestimated by $10-50 \%$.

Ammonia in soils can be constantly formed from biological degradation of organic compounds (Sommer and Hutchings, 2001; Beusen et al., 2008). In agricultural zones, external $\mathrm{N}$ input to soil mainly includes manure and $\mathrm{N}$ fertilizer application, atmospheric deposition of $\mathrm{NO}_{\mathrm{y}}$ and biogenic $\mathrm{N}$ fixation. Atmospheric deposition of $\mathrm{NO}_{\mathrm{y}}$ and biogenic $\mathrm{N}$ fixation could release $\mathrm{NH}_{3}$ gas through soil $\mathrm{N}$ cycling processes, but were not considered in the emission inventory of $\mathrm{NH}_{3}$. Atmospheric deposition of $\mathrm{NO}_{\mathrm{y}}$ might be a negligible source to $\mathrm{N}$ budget in soil at $\mathrm{B}$ zone because of low $\mathrm{NO}_{2}$ concentration (Fig. S4). Globally, the estimated N fixed biologically in agricultural systems was $50-70 \mathrm{Tg} \mathrm{N}$ per year. Soybean was the dominant crop legume and fixed $16.4 \mathrm{Tg} \mathrm{N}$ globally and 5.7 Tg N in the US (Galloway et al., 2008; Herridge et al., 2008). Biogenic $\mathrm{N}$ fixation in agriculture systems followed by soil $\mathrm{N}$ cycling in $\mathrm{B}$ agriculture zones should be investigated in the future in order to identify missing sources.

D zone is located immediately downwind of the zone with intensive anthropogenic emission of $\mathrm{NO}_{\mathrm{x}}$ (Fig. S4). High atmospheric deposition of $\mathrm{NO}_{\mathrm{y}}$ was expected in $\mathrm{D}$ zone. The deposited $\mathrm{NO}_{\mathrm{y}}$ can infiltrate to sub-surface soil and convert into $\mathrm{NH}_{3}$ through soil $\mathrm{N}$ cycling processes. Atmospheric deposition of $\mathrm{NO}_{\mathrm{y}}$ could be one of the important sources for local emissions of $\mathrm{NH}_{3}$ in $\mathrm{D}$ zone and might have contributed to the underestimation of $\mathrm{NH}_{3}$ emissions. Moreover, $\mathrm{N}$ fixed biologically by agriculture systems could also be a potential source at $\mathrm{D}$ zone.

\section{Conclusions}

High spatial-resolution weekly/biweekly ambient $\mathrm{NH}_{3}$ concentration data measured mainly from June 2006 to March 2007 at 74 sites across southern Ontario were analyzed in de- tail. In the remote and rural non-agricultural zones, the AAN was less than $1 \mu \mathrm{g} \mathrm{m}^{-3}$ and the same was true for a few sites in low intensity agricultural zones. Approximately $50 \%$ of the sites had an AAN in the range of $1-3 \mu \mathrm{g} \mathrm{m}^{-3}$ and exceeded the new critical level value. There were eight sites situated inside the intensive livestock production zones having an AAN in the range of 3.6 to $6.1 \mu \mathrm{g} \mathrm{m}^{-3}$. These high $\mathrm{NH}_{3}$ concentration levels could have a potential damage to vegetation.

At remote non-agricultural sites with low $\mathrm{NH}_{3}$ concentrations, local emissions were estimated to contribute a maximum of $0.2 \mu \mathrm{g} \mathrm{m}^{-3}$ to the overall measured concentration, the rest was likely from regional transport which was the dominant contributor during most of the time. Two transport mechanisms were proposed, but needed further validation using high temporal resolution field data and/or high spatial and temporal resolution air quality model simulations. The first mechanism is a combination of bi-directional air-soil and air-plant exchanges of $\mathrm{NH}_{3}$ and transport of air masses containing the so-produced $\mathrm{NH}_{3}$ along the trajectories, and the second mechanisms is transport of $\mathrm{NH}_{4} \mathrm{NO}_{3}$ produced in upstream followed by the release of $\mathrm{NH}_{3}$ from $\mathrm{NH}_{4} \mathrm{NO}_{3}$ at receptor sites. The first mechanism generally took a few weeks transporting $\mathrm{NH}_{3}$ from emission sources in southwestern Ontario to receptor sites in southeastern Ontario, which seems to be consistent with the time-lag in peak concentrations between the two regions. Direct transport of $\mathrm{NH}_{4} \mathrm{NO}_{3}$ should only take a few hours to a few days, but the time of releasing $\mathrm{NH}_{3}$ from $\mathrm{NH}_{4} \mathrm{NO}_{3}$ could be much longer depending on the temperature and humidity conditions. It is likely that the first mechanism is more important than the second one in hot seasons while the opposite should be the case in cold seasons. One unexplained phenomenon was the increase of ambient $\mathrm{NH}_{3}$ level observed in the coldest two weeks at 20 out of 74 sites. The 20 sites were distributed along a banana-shaped curve in $\sim 600 \mathrm{~km}$ length extending from southwestern to southeastern Ontario. The mechanisms causing the high $\mathrm{NH}_{3}$ at these sites are not clear and require further studies.

In two agriculture zones, the observed high concentrations of $\mathrm{NH}_{3}$ were contradictory to the low emissions in the recently developed emission inventory. Emissions of $\mathrm{NH}_{3}$ at the two zones were likely underestimated. $\mathrm{N}$ fixed biologically in agricultural systems and/or atmospheric deposition of $\mathrm{NO}_{\mathrm{y}}$ followed by soil $\mathrm{N}$ cycling processes should be considered in future development of $\mathrm{NH}_{3}$ emission inventory to explain the missing sources.

\section{Supplementary material related to this article is available online at http://www.biogeosciences.net/10/ 7913/2013/bg-10-7913-2013-supplement.pdf.}


Acknowledgements. We greatly appreciate Q. Zheng for proving emission inventory data, J. Narayan for providing land use map, and all the people who contributed to the field data collection and data quality control.

Edited by: X. Wang

\section{References}

Asman, W. A., Sutton, M. A., and Schjørring, J. K.: Ammonia: emission, atmospheric transport and deposition, New Phytol., 139, 27-48, 1998.

Bein, K. J., Zhao, Y., Johnston, M. V., Evans, G. J., and Wexler, A. S.: Extratropical waves transport boreal wildfire emissions and drive regional air quality dynamics, J. Geophys. Res., 113, D23213, doi:10.1029/2008jd010169, 2008.

Beusen, A., Bouwman, A. F., Heuberger, P., Van Drecht, G., and Van Der Hoek, K. W.: Bottom-up uncertainty estimates of global ammonia emissions from global agricultural production systems, Atmos. Environ., 42, 6067-6077, 2008.

Cape, J. N., Tang, Y. S., Van Dijk, N., Love, L., Sutton, M. A., and Palmer, S.: Concentrations of ammonia and nitrogen dioxide at roadside verges, and their contribution to nitrogen deposition, Environ. Pollut., 132, 469-478, 2004.

Cape, J. N., Van der Eerden, L. J., Sheppard, L. J., Leith, I. D., and Sutton, M. A.: Evidence for changing the critical level for ammonia, Environ. Pollut., 157, 1033-1037, 2009.

Chan, C. K. and Yao, X.: Air pollution in mega cities in China, Atmos. Environ., 42, 1-42, 2008.

Dabney, S. M. and Bouldin, D. R. : Apparent deposition velocity and compensation point of ammonia inferred from gradient measurements above and through alfalfa, Atmos. Environ., 24, 26552666, 1990.

Edwards, K. A., McCulloch, J., Peter Kershaw, G., and Jefferies, R. L.: Soil microbial and nutrient dynamics in a wet Arctic sedge meadow in late winter and early spring, Soil Biol. Biochem., 38, 2843-2851, 2006.

Environment Canada: Emissions to air, available at: http://www.ec.gc.ca/indicateurs-indicators/default.asp?lang= en\&n=FE578F55-1 (last access: 20 October 2013), 2013.

Flechard, C. R., Massad, R.-S., Loubet, B., Personne, E., Simpson, D., Bash, J. O., Cooter, E. J., Nemitz, E., and Sutton, M. A.: Advances in understanding, models and parameterizations of biosphere-atmosphere ammonia exchange, Biogeosciences, 10, 5183-5225, doi:10.5194/bg-10-5183-2013, 2013.

Galloway, J. N., Townsend, A. R., Erisman, J. W., Bekunda, M., Cai, Z., Freney, J. R., Martinelli, L. A., Seitzinger, S. P., and Sutton, M. A.: Transformation of the nitrogen cycle: recent trends, questions, and potential solutions, Science, 320, 889-892, 2008.

Groffman, P. M., Driscoll, C. T., Fahey, T. J., Hardy, J. P., Fitzhugh, R. D., and Tierney, G. L.: Colder soils in a warmer world: a snow manipulation study in a northern hardwood forest ecosystem, Biogeochemistry, 56, 135-150, 2001.

Grunditz, C. and Dalhammar, G.: Development of nitrification inhibition assays using pure cultures of Nitrosomonas and Nitrobacter, Water Res., 35, 433-440, 2001.

Herridge, D. F., Peoples, M. B., and Boddey, R. M.: Global inputs of biological nitrogen fixation in agricultural systems, Plant Soil, 311, 1-18, 2008.
Johnson, M. D., Armstrong, D. K., Sanford, B. V., Telford, P. G., and Rutka, M. A.: Paleozoic and Mesozoic geology of Ontario, in: Geology of Ontario, Ontario Geological Survey, Toronto, edited by: Thurston, P. C., Williams, H. R., Sutcliffe, R. H., and Stott, G. M., Special Vol. 4, Part 2, 907-1010. 1992.

Lillyman, C., Buset, K., and Mullins, D.: Canadian atmospheric assessment of agricultural ammonia, National Agri-Environmental Standards, Environment Canada, Gatineau, Que, 2009.

Marshall, T. J. and J. W. Holmes: Soil Physics, 2nd ed., Cambridge Univ. Press, New York, 1988.

Misselbrook, T. H., Webb, J., Chadwick, D. R., Ellis, S., and Pain, B. F.: Gaseous emissions from outdoor concrete yards used by livestock, Atmos. Environ., 35, 5331-5338, 2001.

Misselbrook, T. H., Nicholson, F. A., and Chambers, B. J.: Predicting ammonia losses following the application of livestock manure to land, Bioresource Technol., 96, 159-168, 2005.

Nemergut, D. R., Costello, E. K., Meyer, A. F., Pescador, M. Y., Weintraub, M. N., and Schmidt, S. K.: Structure and function of alpine and arctic soil microbial communities, Res. Microbiol., 156, 775-784, 2005.

Pagans, E., Barrena, R., Font, X., and Sanchez, A.: Ammonia emissions from the composting of different organic wastes, Dependency on process temperature, Chemosphere, 62, 1534-1542, 2006.

Puchalski, M. A., Sather, M. E., Walker, J. T., Lehmann, C. M., Gay, D. A., Mathew, J., and Robarge, W. P.: Passive ammonia monitoring in the United States: Comparing three different sampling devices, J. Environ. Monitor., 13, 3156-3167, 2011.

Roadman, M. J., Scudlark, J. R., Meisinger, J. J., and Ullman, W. J.: Validation of Ogawa passive samplers for the determination of gaseous ammonia concentrations in agricultural settings, Atmos. Environ., 37, 2317-2325, 2003.

Salazar, F., Martínez-Lagos, J., Alfaro, M., and Misselbrook, T.: Ammonia emissions from urea application to permanent pasture on a volcanic soil, Atmos. Environ., 61, 395-399, 2012.

Seinfeld, J. H. and Pandis, S. N.: Atmospheric chemistry and physics: from air pollution to climate change, Wiley and Sons, New Jersey, 1203 pp., 2006.

Sheppard, S. C., Bittman, S., and Bruulsema, T. W.: Monthly ammonia emissions from fertilizers in 12 Canadian Ecoregions, Can. J. Soil. Sci., 90, 113-127, 2010.

Sommer, S. G. and Hutchings, N. J.: Ammonia emission from field applied manure and its reduction - invited paper, Eur. J. Agron., 15, 1-15, 2001.

Sutton, M. A., Milford, C., Dragosits, U., Place, C. J., Singles, R. J., Smith, R. I., Pitcairn, C., Fowler, D., Hill, J., and ApSimon, H. M.: Dispersion, deposition and impacts of atmospheric ammonia: quantifying local budgets and spatial variability, Environ. Pollut., 102, 349-361, 1998.

Sutton, M. A., Miners, B., Tang, Y. S., Milford, C., Wyers, G. P., Duyzer, J. H., and Fowler, D.: Comparison of low cost measurement techniques for long-term monitoring of atmospheric ammonia, J. Environ. Monitor., 3, 446-453, 2001.

Sutton, M. A., Reis, S., and Baker, S. M. H.: Atmospheric Ammonia: Detecting emission changes and environmental impacts, Springer, 464 pp., 2009.

Theobald, M. R., Løfstrøm, P., Walker, J., Andersen, H. V., Pedersen, P., Vallejo, A., and Sutton, M. A.: An intercomparison of models used to simulate the short-range atmospheric dispersion 
of agricultural ammonia emissions, Environ. Modell. Softw., 37, 90-102, 2012.

Walker, J. T., Jones, M. R., Bash, J. O., Myles, L., Meyers, T., Schwede, D., Herrick, J., Nemitz, E., and Robarge, W.: Processes of ammonia air-surface exchange in a fertilized Zea mays canopy, Biogeosciences, 10, 981-998, doi:10.5194/bg-10-9812013, 2013.

Wen, D., Lin, J. C., Zhang, L., Vet, R., and Moran, M. D.: Modeling atmospheric ammonia and ammonium using a stochastic Lagrangian air quality model (STILT-Chem v0.7), Geosci. Model Dev., 6, 327-344, doi:10.5194/gmd-6-327-2013, 2013.

Yao, X. H., Rehbein, P. J., Lee, C. J., Evans, G. J., Corbin, J., and Jeong, C.: A study on the extent of neutralization of sulphate aerosol through laboratory and field experiments using an ATOFMS and a GPIC, Atmos. Environ., 45, 6251-6256, 2011.

Yao, X. H. and Zhang, L.: Supermicron modes of ammonium ions related to fog in rural atmosphere, Atmos. Chem. Phys., 12, 11165-11178, doi:10.5194/acp-12-11165-2012, 2012.

Yao, X. H., Hu, Q., Zhang, L., Evans, G. J., Godri, K. J., and Ng, A. C.: Is vehicular emission a significant contributor to ammonia in the urban atmosphere?, Atmos. Environ., 80, 499-506, 2013.

Zbieranowski, A. L. and Aherne, J.: Spatial and temporal concentration of ambient atmospheric ammonia in southern Ontario, Canada, Atmos. Environ., 62, 441-450, 2012.
Zbieranowski, A. L. and Aherne, J.: Ambient concentrations of atmospheric ammonia, nitrogen dioxide and nitric acid in an intensive agricultural region, Atmos. Environ., 70, 289-299, 2013.

Zhang, L., Vet, R., Wiebe, A., Mihele, C., Sukloff, B., Chan, E., Moran, M. D., and Iqbal, S.: Characterization of the sizesegregated water-soluble inorganic ions at eight Canadian rural sites, Atmos. Chem. Phys., 8, 7133-7151, doi:10.5194/acp-87133-2008, 2008.

Zhang, L., Wright, L. P., and Asman, W.: Bi-directional airsurface exchange of atmospheric ammonia: A review of measurements and a development of a big-leaf model for applications in regional-scale air-quality models, J. Geophys. Res., 115, D20310, doi:10.1029/2009JD013589, 2010.

Zhang, Q., Jimenez, J. L., Canagaratna, M. R., Allan, J. D., Coe, H., Ulbrich, I., Alfarra, M. R., Takami, A., Middlebrook, A. M., and Sun, Y. L.: Ubiquity and dominance of oxygenated species in organic aerosols in anthropogenically-influenced Northern Hemisphere midlatitudes, Geophys. Res. Lett., 34, L13801, doi:10.1029/2007GL029979, 2007.

Zhang, R., Khalizov, A., Wang, L., Hu, M., and Xu, W.: Nucleation and growth of nanoparticles in the atmosphere, Chem. Rev., 112, 1957-2011, 2012. 